\title{
Relationships Between Director Profile And Restatements Of Suspect Earnings
}

\author{
Joe Ueng, University of St. Thomas, USA \\ Daryl Koehn, University of St. Thomas, USA \\ Ching Liang Chang, Kainan University, Taiwan, R.O.C.
}

\begin{abstract}
The large number of recent earnings restatements suggests that boards have not been discharging their fiduciary duties very well. This paper examines which director traits, if any, are correlated with the need to restate suspect earnings. We find that the only significant aspect of director profile is director independence: boards with a larger percentage of outside directors are less likely to have restated suspect earnings that boards with a lesser percentage. The paper concludes with some thoughts on why current research practice of focusing on formal corporate governance (board composition, board traits, etc.) needs to be supplemented with research into power dynamics.
\end{abstract}

Keywords: Restatement, Suspect Earnings, Directors, Board of Directors

\section{INTRODUCTION}

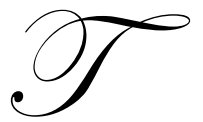

he recent spate of business ethics scandals and corporate earnings restatements has focused attention on the performance of board directors both in the US and abroad. Regulators from around the world have begun to collaborate, drafting memoranda of understanding addressing joint enforcement issues and cross-border regulatory responsibilities. Corporate governance has emerged as a major issue, with regulators focusing not only on insider trading and market manipulation by directors but also on false or misleading corporate disclosures. Judges and legislators have taken note of the scandals. Recent court rulings in the US have assigned more personal responsibility to directors. New laws throughout the Asia-Pacific rim are having a similar effect (Brennan, 2005).

The response to earnings restatements has been cultural as well as legislative and judicial. Investors have been particularly concerned: Restatements at Cendant, Microstrategy, and Sunbeam led to a combined $\$ 23$ billion drop in market value when the restatements were announced (Turner et al, 2001). Shareholders have responded by becoming increasingly sophisticated in their legal strategies and more alert when monitoring individual companies. They have not been shy about pressuring companies to shed particular directors. Shareholders have been aided by the advent of corporate governance rating agencies, such as Standard \& Poor's, Governance Metrics International (GMI), and Institutional Shareholder Services (ISS), agencies which assign a numerical quotient purportedly indicating how good a firm's governance is. Insurance companies have followed these debates with interest. Iinsurance firms offering Director and Officer Liability Insurance carefully track claims against directors. Claims are up substantially. Chubb reports that in Asia, new claims shot up from around 430 in mid-2004 to over 600 by mid-2005 (Brennan, 2005).

In this scandal-tainted environment, investors are seeking ways to identify which directors are most likely to be conscientious stewards of shareholder interests. This paper addresses the issue of whether specific director traits correlate with a greater probability of restatements of suspect earnings. The literature on corporate governance and restatements is thin, so our paper makes a contribution to this under-explored area. Furthermore, while some director traits or characteristics (e.g., director independence) have been examined by other scholars, other characteristics that might affect a director's ability or willingness to identify and object to earnings manipulation 
have received little attention This paper seeks to correlate a full, robust director profile with the performance of the firms on which these directors serve.

The paper has 5 sections: 1) Literature review regarding restatements and possible connections with governance factors, including director profile; 2) Presentation and discussion of hypotheses; 3) Methodology; 4) Discussion of results; and 5) Concluding thoughts.

\section{REVIEW OF LITERATURE CONCERNING RESTATEMENTS AND DIRECTOR PROFILE}

While numerous papers have explored governance issues (e.g., the possible beneficial effects of having an audit committee or of longer auditor tenure), comparatively less research has been done regarding earnings restatements. This lacuna is somewhat surprising, given that the General Accounting Office reports that the number of earnings restatements is soaring (GAO, 2002). The GAO identified 919 restatements between January 1, 1997 and June 30, 2002; the Huron Consulting Group released a study of 1, 207 restating firms for the period 1998-2002. $\mathrm{Wu}$ (2002) also documented a dramatic increase in financial restatements throughout the 1990s, even before Sarbanes-Oxley's rules requiring executive certification of earnings became law. Small firms have historically been more likely to restate than larger firms, but the dynamics seem to be shifting. In recent years, restatements of suspect earnings have increasingly occurred at large, supposedly profitable firms (Owers and Lin, 2002). While some researchers contend that the upsurge in restatements is due more to aggressive accounting than to outright fraud, fraud should not be dismissed as a possible cause. A 1998 survey of CFOs revealed that $45 \%$ of those questioned had been asked to misrepresent their companies' financial results, and $38 \%$ of the total sample complied with the request (Barr, 1998). Directors may be similarly tempted to falsify results.

Several studies have shown that restatements lead to short-term drops in market value. The wealth effect depends on the type of restatement. Restatements stemming from mismanagement have a negative effect, while the effect of other types of restatements is less pronounced (Salavei and Moore, 2005). Owers et al (2002) categorized types or restatements and discovered that investor reaction was most negative when the restatements involved accounting irregularities or errors. Akhigbe et al (2005) also tied market effects to the type of earnings restatements: earnings restatements are associated with a decline in the firm's value when the market attributes the restatement to a revenue adjustment and/or pressure from the auditor or SEC. Palmrose et al (2001) looked at 403 restatements between 1995 and 1999 and found significant negative average abnormal returns of around 9\% during a 2-day announcement window; the extent of the reaction depended on the circumstances leading to the restatement. As one might surmise, the reaction was more pronounced when mismanagement was involved or when the restatement was initiated by auditors rather than by management itself. If the restatement increased, rather than decreased, current income, the response was muted. Wilson (2005) showed that restatements produce a short-term decline in investor confidence in firms' financial statements but the effect is transitory, typically disappearing within two quarters. After studying quarterly earnings restatements, Livnat and Tan (2004) concluded that investors impute a lower earnings valuation co-efficient to the earnings of corporations that go on to restate earnings; investors also assign a lower co-efficient to the future earnings of forms that have restated one or more times in the past.

As we noted above, comparatively less work has been done regarding the financial and governance characteristics of restating firms and is somewhat dated. Kinney and McDaniel's groundbreaking 1989 study of earnings restatements revealed that restating firms tended to be smaller and slower growing than other firms in the same industry (Kinney and McDaniel, 1989). Richardson et al (2002) investigated restating firms from 1971-2000. They concluded that restating firms have higher levels of outstanding debt and try to maintain consecutive quarters of positive growth. Other studies have explored whether accruals are implicated in earnings restatements. Richardson et al (2002) found that restating firms report significantly larger accruals than non-restating firms. Accruals at restaters averaged $8.7 \%$ of total assets versus $3.9 \%$ at non-restaters. The same study found that restaters tend to be high growth companies with high P/E and low book-to-market ratios. DeFond and Jiambalvo (1991) focused on firms that corrected earnings overstatements. These firms were more likely to be slow-growing and less likely to have audit committees. Dechow et al (1996) reported that earnings manipulating firms are more likely to have a founding CEO and less likely to have either audit committees or large outside blockholders. 
Beasley (1996) looked at firms subject to Accounting and Auditing Enforcement Releases (AAERs). He found accounting fraud to be less likely at companies with a greater presence of outside directors. Farber (2004) confirmed that fraud companies had few audit committees and few outside directors (measured in absolute numbers and as a percentage of directors). He also found that fraud companies (87 firms identified by SEC as involved in fraud) had a higher percentage of CEOs serving as board chairman.

Agrawal and Chadwa (2002) have written one of the few papers to focus on earnings restatements and governance metrics. Their study examined 172 restaters. Most of these restatements (142) were initiated by the firms themselves; 21 were forced by regulators. Board independence and the existence of audit committees had no effect on the likelihood of firms' restating earnings. A few studies have explored the possible relation between auditor tenure and the quality of financial statements. Myers et al (2004) paired companies that restated between January 1997 and October 2001 with non-restaters from the same period. That study found that auditor tenure is not significantly correlated with the likelihood of restatements of annual earnings for the entire sample, although misstatements of quarterly financial reports become more probable as auditor tenure increases.

Recently researchers have begun exploring the possible connection between forms of executive compensation and earnings misrepresentations. Levels of executive pay have exploded in the United States, largely because of the increasing use of stock options to compensate executives. The Securities and Exchange Commission has explicitly linked executive compensation - specifically, stock options - with accounting fraud. For his part, Federal Reserve Chairman Alan Greenspan has argued that "the highly desirable spread of shareholding and options among business managers perversely created incentives to artificially inflate reported earnings in order to keep stock prices high and rising." (Greenspan quoted in Provenzo, 2002, p.1). Some academic studies are starting to appear that consider whether stock options tempt executives to manipulate the numbers and make subsequent earnings restatements more likely (Harris, 2004; Burns and Kedia, 2003). Harris (2004) and Erickson et al (2003) found that accounting fraud becomes more likely when a greater percentage of an executive's compensation is stock-based. Collins et al (2005) reported that when senior managers own more equity, they were less likely to get fired or to receive lower bonuses in the event of an earnings restatement. U.S. firms, which have used stock options far more than their European and Asian counterparts, have been more likely than their foreign peers to manage earnings to create small positive surprises, while avoiding large drops in earnings (Brown and Higgins, 2001). Brown and Higgins concluded that such earnings management is designed to boost stock prices and to keep options in the money.

In only about half of the cases of income-reducing restatements do firms take steps to penalize management. Whether or not a firm penalizes management depends upon the extent of the restatement and whether the board of directors and institutional investors are equity owners (Collins et al, 2005). The higher the level of director equity ownership, the greater the penalty imposed. The same positive relation holds with respect to institutional investor equity. At this point, little is known about whether executives who keep their jobs despite restatements suffer a bonus penalty. Fich and Shivdasani (2005) have delved into the reputational effect of financial fraud on outside directors. After a lawsuit for financial fraud, outside directors are not removed from the board at a higher rate than in non-fraud firms but such directors do lose board seats they had at other companies. The more severe the fraud and the greater the responsibility of the individual outside director for the fraud, the more board seats he or she loses. When fraud-associated directors leave the boards of firms that are interlocked with the fraudulent firm, the value of these other firms increases significantly. Anecdotal evidence suggests that directors connected with severe frauds lose board seats. At the time of Enron's collapse, the firm's outside directors (11) had a total of 21 seats at other firms. As of early 2006, only two former Enron directors had board seats. Neither of these directors was among the Enron board members who wound up paying shareholders out of their own pockets.

\section{PRESENTATION AND DISCUSSION OF HYPOTHESES}

This paper explores possible relations between aspects of the profile of public company directors and the likelihood that a director's firm has restated suspect earnings. Instead of focusing on a single aspect or even several dimensions of the director profile, we consider a robust or full profile, looking at seven factors: 1) whether the director owns equity; 2) how long the director has served; 3) whether the director serves on multiple boards; 4) whether the director is a CEO of a company that had failed; 5) whether the director is female; 6) whether the director 
is an outside/independent director; and 7) how large is the firm. If some profile characteristics turn out to be significant, then both companies and governance experts should pay closer attention to these features. On the other hand, if no features stand out as significant, then researchers interested in possible causes of fraud and in checks upon unethical behavior must look beyond superficial features of directors (age, gender, number of directorships held, etc.) and probe more deeply into governance dynamics.

Hypothesis 1: The Greater the Equity Ownership of a Director, the Greater the Probability that the Firm on Whose Board He or She Serves Has Restated Suspect Earnings.

Directors who receive fees get their payment regardless of how well the firm performs. However, when board members are paid in part with shares, they have an incentive to go along with suspect earnings, particularly when the firm's earnings are higher than they would have been without the earnings manipulation. Higher earnings should translate into a higher share price and thus yield greater compensation for directors with equity ownership. The same arguments that provided the rationale for the first hypothesis apply here. Therefore, we posit that equity directors will have a greater probability of being connected with a restating firm than directors who receive no equity. Whether a director has zero share of the firm is used to test this hypothesis.

Hypothesis 2: The Longer a Director Has Served on a Board, the Greater the Probability that the Firm on Which He or She Serves Has Restated Suspect Earnings.

Director who have served on a board a long time are, in theory, more knowledgeable about the firm. They may have better relations with executives and thus feel more comfortable in asking probing questions. However, there are numerous reasons to be concerned about long-serving directors. Long tenure may be the result of generous pay packages; directors may be reluctant to get off the proverbial "gravy train." A director with long tenure may say little that is meaningful at board meetings in order not to antagonize management and to preserve his or her board position.

Prolonged service poses another danger: if a board member begins to suspect financial shenanigans in year $\mathrm{X}$, he or she likely will begin to suspect problems with financial statements from prior years X-1 or X-2. As a board member, the director approved those prior statements. To confront executives at a later point inevitably calls into question the goodness of the director's service and invites lawsuits, which may name this director as a defendant and seek to hold him or her personally liable. So, while prolonged tenure may create more board experience, it may also function as an incentive not to ask tough questions.

With the legal system is now holding directors more personally liable than in the past, we hypothesize that new directors coming onto boards will be more active and inquiring than longer serving board members. With this hypothesis, we test the possibility that directors with lower average tenure are more diligent and thus less likely to be on the boards of firms forced to restate suspect earnings. In this study, we use the number of director that have served on the board for longer than 15 years to measure the variable.

Hypothesis 3: The Greater the Number of Board Appointments Held by a Director, the Greater the Probability that the Firm on Which He or She Serves Has Restated Suspect Earnings.

Directors serving on multiple boards may be too thinly stretched to be effective. At one point, President Bill Clinton's advisor Vernon Jordan, Jr. sat on 13 boards; the head of one large Canadian firm boasted of sitting on 21 boards simultaneously. There is another potential problem: the more boards on which a director serves, the greater the likelihood that he or she will be part of an interlocked board. An interlock occurs when a director of firm A serves on B's board, while a director of firm B serves on A's board. Hallock (1997) has estimated that about 20\% of U.S. companies have current or retired employees sitting on the board of another company. In about $8 \%$ of these companies, a CEO director is reciprocally interlocked with another CEO.

Little work has been done on the possible connection between numerous board appointments and accounting restatements of suspect earnings. Ferris et al (2003) contend that directors with multiple appointments do not shirk their duties and are not associated with a greater likelihood of securities fraud litigation. However, several 
others have found multiple directorships and interlocks to be problematic. Core et al (1999), Fich and White (2001), Fich and White (2003) and Hallock (1997) found that CEO pay is higher in firms with interlocked directors (although the difference is reduced when the pay is controlled for the size of the firm and other CEO characteristics).

Hypothesis 4: A Director Who Is the CEO of a Failed Company Has a Greater Probability of Being on a Board of a Company that Has Restated Suspect Earnings.

Many current directors have been drawn from firms that went bankrupt. The information services company Experian reported that, by 1998, around 750,000 UK directors (out of 2.8 million studied) had been involved with a failed company (BBC, 1998). Experian released figures showing that approximately $7 \%$ of UK corporate directors active in 2001 were involved in more than one failed company. Around 3000 of these directors were associated with more than 10 failed companies (SMT, 2001). By 2004, 11, 352 of the 16, 210 companies that failed had directors who had been on the board of at least one failed firm (ICC Information, 2004).

The literature on the firm performance of companies with directors from failed companies is slim. There certainly is a perception that such directors are likely to be ineffective. If they were skilled at strategizing and monitoring, why did their own companies fail? There are other reasons to question whether directors of failed companies should be on other firms' boards. If they are no longer CEOs, failed directors are no longer drawing substantial corporate salaries. Such directors may be more dependent on their director pay than other board members. If so, they may be loath to ask probing questions, and fraud may escape their notice. Or they may themselves have been involved in fraud at an earlier stage of their careers. Bankruptcy professionals have estimated that up to $10 \%$ of corporate failures may be caused by fraudulent actions on the part of corporate directors, yet few of them suffer any kind of penalty (BBC, 1998).

On the other hand, some theorists and politicians have argued that banning so-called "rogue directors" from future service does not reduce fraud but instead hampers entrepreneurialism. They are pressing for revisions to bankruptcy laws in countries like Italy that at present restrict rogue directors (BBC, 1998). It is important, therefore, to ascertain whether failed company directors tend to be associated with firms that restate earnings. In this study, we use the number of directors of failed companies on the board to measure the variable.

Hypothesis 5: A Female Director Has a Lesser Probability of Being on a Board of a Company that Has Restated Suspect Earnings.

Several studies have found that boards with more female directors perform better, prompting numerous governance watchdogs to press for more diverse boards. A study by the Public Policy Forum (2003), a Milwaukee research group, found that Wisconsin companies with one or more women on their boards outperformed those with no women. A recent study of firm performance in Japan and Australia also considered the female director ratio and found it to be positively correlated with firm performance (Bonn et al, 2004). Filatotchev and Toms (2003) reported that that textile companies with more gender and ethnically diverse boards performed better financially and were less likely to fail. Van der Zahn (2004) examined the percentage of female directors of South African firms and found it to be positively correlated with the intellectual capital performance of the firm. If one posits that intellectual capital translates into higher returns, then boards with more female directors should be under less pressure to cook the books. Less pressure shared lead to a lower probability of subsequent restatement of earnings.

Catalyst (2004) divided the number of women in top management into quartiles and then looked for correlations between these layers and return on equity (ROE) (defined as the ratio of income before extraordinary items to average shareholder equity for a given year) and total return to shareholders (TRS) (defined as the sum of stock price appreciation and reinvestment of dividends declared for a given calendar year). The Catalyst study analyzed the results by industry. In each of the 5 industries studied, ROE was highest in companies with the largest representation of women in top management. TRS was highest in 4 out of 5 industries. Ranzijn and Vergoom (2004) studied 80 publicly listed firms headquartered in the Netherlands and considered these companies' performance for the period from 1996 to 2003. They found a significant relation between the number of women in supervisory positions and TRS, but no relation with ROE. 
Milliken and Martins (1996) have shown the diversity does affect group performance, but the mechanism producing the effect is unclear. Cox (1993) and Jehn et al (2000) argued that a group with greater diversity entertain more ideas and perspectives and brings more skills to bear on solving problems. Diverse corporate groups may also be more savvy about consumer needs. This line of argument gains some support from Adler's (2001, p. 30) finding that "companies with the highest percentages of female executives delivered earnings far in excess of the median for other large firms in their industries."

Although the studies looked at women managers, not female directors, one can extrapolate and hypothesize that more gender diverse boards will have better financial results and thus be under less pressure to manipulate or manufacture earnings. Indirect support for this hypothesis comes from Dechow et al (2004) who discovered that firms with greater gender diversity have fewer securitized assets (which are notoriously subject to easy manipulation) and report smaller gains in connection with such assets.

Hypothesis 6: A Board with a Smaller Percentage of Outside Directors Has a Greater Probability of Being Associated with a Firm that Has Restated Suspect Earnings.

Independent or outside directors are often thought to be more effective monitors or checks on executives than internal directors. At least three reasons are given: (1) such directors have independent careers and thus feel no need to kowtow to powerful executives who have the power to fire inside directors; (2) independent directors typically have extensive experience and can bring an outsider's perspective to bear on board level deliberations; and (3) since these directors are not beholden to the firm for the bulk of their livelihood, they feel more free to resist or challenge insider CEOs and CFOs. In this era of increased director liability, outside directors may be more inclined to press auditors to investigate thoroughly and to test financial results carefully. If several directors are willing to speak up, others may feel empowered to do so as well, fostering closer and more sustained scrutiny of managerial behavior and of financial statements.

Bhojraj and Sengupta (2003) found that stronger outside control of the board correlates with higher bond ratings, which would suggest that firms with outside earnings are at least perceived as being more sound. According to a Canadian study done by Park and Shin (2004), firms with outside directors drawn from financial intermediaries and/or from institutional investors tended to have fewer abnormal accruals. Farber (2004) found that firms identified by the SEC as fraudulently manipulating earnings had fewer outside directors, both in absolute numbers and as a percentage of total directors, prompting him to conclude that fraud companies have poorer governance controls than firms in the control sample. Farber's findings are consistent with those of Dechow et al (1996) and Beasley (1996) who claim that fraud companies are more likely to have boards dominated by insider directors. With this hypothesis, we test whether director independence correlated with actual restatements of manipulated or misrepresented earnings. In this study, we use the percentage of outside directors to measure the variable. The percentage of outside directors is calculated as the number of outside directors divided by the number of total directors.

Hypothesis 7: A Director of a Larger Firm Has a Greater Probability of Being on the Board of a Firm that Has Restated Suspect Earnings.

Larger firms have more complex lines of business which provides more opportunity to manipulate earnings. If the company is paying their auditor a very large fee-as large companies typically do - executives are in a position to exert considerable pressure on auditors to endorse (or at least turn a blind eye to) aggressive accounting techniques, techniques that subsequently lead to earnings restatements. In addition, fund managers and institutional investors may pressure larger firms to deliver strong earnings and to meet projected earnings targets. Almost all business commentators agree that such pressure has steadily increased over the past five years. Finally, larger firms were among the first to use stock options to try to align the interests of managers and shareholders. As we noted previously, the use of stock options has correlated with earnings restatements. For these three reasons, we hypothesize that there will be a positive correlation between directorships in larger firms (measured in terms of both annual revenue and the number of employees) and earnings restatements. In this study, we use the number of a given firm's employees to measure the size of that firm. 


\section{METHODOLOGY}

A restatement occurs when a company revises official, previously announced earnings. Companies restate for a variety of reasons. Restatements may occur when accounting rules change, when a firm discontinues operations, or when firms merge. Restatements also occur when a firm is discovered to have manipulated earnings. Our database includes only restatements involving suspect earnings by publicly traded firms. When restatements of suspect earnings do not involve outright fraud, they typically stem from a violation of Generally Accepted Accounting Principles and involve problems with revenue overstatement and/or expense understatement. On the revenue side, restaters were caught prematurely booking revenue, channel stuffing, inflating sales or recording revenues from sales before the items were actually shipped. According to the previously cited GAO study, $38 \%$ of restatements involve overly aggressive reporting of revenues. Expense-side "sins" included, but were not limited to, improper capitalization of expenses, overstating inventory, and creating fake inventory. Other types of offenses included lease accounting and barter transactions.

We excluded all restatements resulting from changes in accounting rules, mergers and acquisitions, or other events that have nothing to do with manipulated or fraudulent earnings. Only those restatements that reduced previously announced earnings were included. The database includes firms forced by the SEC to restate earnings and firms whose managers self-initiated restatements of suspect earnings.

The list of restating companies was developed using companies already identified in the aforementioned GAO study as firms restating suspect earnings. Following the GAO methodology and that employed by other researchers who have constructed restatement databases, we used the search engine Google, searching on key words "earnings restatement," "restate," "restated," "restating," and "restatement" and then did additional research to unearth why the company restated. By perusing the resulting hits, we were able to ascertain whether a particular firm was forced or pressured to restate earnings because the earnings were in some way deemed suspect (improper revenue or expense recognition, improper accounting for leases, other accounting irregularities, overt fraud, etc.). We identified more than 300 firms that restated earnings. After scrubbing the data to include only income-lowering, suspect earnings restatements by large cap firms, we had 96 firms in our restating database. Using SIC codes and firm size, we paired each restating firm with a non-restating firm, creating a database with 192 firms. Then we double-checked that each non-restating firm did not restate during the study period.

We restricted our focus to firms that restated earnings during the period 2002 through 2004 . The SarbanesOxley bill was signed into legislation in 2002. Many firms restated earnings in 2002. Some executives may have decided that now was the time to come clean about past earnings manipulations. Our database is designed to counter any restatement bias introduced by SOX: all sample firms restated 2002, 2003, or 2004 annual earnings. We excluded 2005 reported restatements because firms were still restating 2005 financials in 2006. In addition, since SOX applies only to firms with annual revenue of more than $\$ 75$ million, we include only firms of this size. All firms in the database were subject to SOX, so, again, there is no bias toward (or against) restatement resulting from this law.

For both restaters and non-restaters, all director profile variables were measured as of the year (2001) prior to the restating window (2002-2004). The director profiles came from the Corporate Library governance database for 2001. The extensive database includes director data from 1506 S \& P firms. Table 1 lists the director traits we studied.

The GAO study found that large cap companies (averaging \$2 billion in assets) were more likely to restate than smaller companies. Therefore, we controlled for size as proxied by market value, number of employees, and asset size with respect to both groups. We also controlled for industry effects, matching each restater with a nonrestater with the same first two digits of the code so that we could do a paired company analysis.

We conducted a logistic regression analysis to evaluate the likelihood that the firm had restated earnings. Earnings restatement score was recoded as 1 if the firm restated; earnings 0 otherwise. This score is modeled as follows: 
$\mathrm{P}($ Restate Earnings $=1)=1 /\left\{1+\mathrm{e}^{-\mathrm{y}}\right\}$

Where $y=\alpha_{0}+\beta_{1} *$ VAR $1+\beta_{2} *$ VAR $2+\beta_{3} *$ VAR $3+\ldots \ldots . . .37 *$ VAR9

VAR 1-VAR 9 are director characteristics (e.g., gender, length of board tenure, etc.)

To control for the impact of firm's size in the analysis, we included the firm's number of employees as a proxy for firm size. According to our model, the probability of a firm restating suspect earnings is a function of size, and the profile of the board director. Table One presents industry distribution of sample firms in the study. The distribution does not reveal a biased sample.

Table 1

Industry Distribution of Sample Firms in The Study.

This table presents the industry distribution of sample firms in the study. The first two digits of SIC code was used to select nonrestater paired firm for every restater. In addition, the size of the non-restaters was employed to match the size the restaters. Total number of restaters is 96 and 96 non- restaters were selected to match the restaters.

\begin{tabular}{|c|c|c|c|}
\hline $\begin{array}{c}\text { SIC Code } \\
\text { First two digits }\end{array}$ & \# of firms & Description & Percentage \\
\hline 10 & 2 & gold ores & $1 \%$ \\
\hline 13 & 6 & crude petroleum and natural gas & 3.1 \\
\hline 15 & 2 & operative builders & 1 \\
\hline 16 & 2 & heavy construction, nec & 1 \\
\hline 20 & 6 & meat packing plants & 3.1 \\
\hline 21 & 2 & Cigarettes & 1 \\
\hline 26 & 4 & paper mills & 2.1 \\
\hline 28 & 8 & indust'l inorganic chemicals, nec & 4 \\
\hline 29 & 2 & lubricating oils and greases & 1 \\
\hline 30 & 2 & tires and inner tubes & 1 \\
\hline 33 & 2 & primary aluminum & 1 \\
\hline 34 & 2 & mis. fabricated metal products & 1 \\
\hline 35 & 18 & oil and gas field machinery & 9.3 \\
\hline 36 & 4 & semiconductors/related devices & 2.1 \\
\hline 37 & 6 & motor vehicle parts/accessories & 3.1 \\
\hline 38 & 10 & search and navigation equipment & 5.2 \\
\hline 47 & 2 & travel agencies & 1 \\
\hline 48 & 10 & telephon communications not radio & 5.2 \\
\hline 49 & 28 & electric services & 14.5 \\
\hline 50 & 2 & electronic parts and equipment & 1 \\
\hline 51 & 4 & drugs/proprietary/sundries & 2.1 \\
\hline 53 & 10 & department stores & 5.2 \\
\hline 56 & 6 & family clothing stores & 3.1 \\
\hline 57 & 2 & radio, $\mathrm{tv}, \&$ electronic stores & 1 \\
\hline 58 & 6 & eating places & 3.1 \\
\hline 59 & 4 & drug stores/proprietary stores & 2.1 \\
\hline 61 & 4 & personal credit institutions & 2.1 \\
\hline 63 & 4 & hospital/medical service plans & 2.1 \\
\hline 67 & 8 & bank holding companies & 4 \\
\hline 73 & 20 & advertising agencies & 10.4 \\
\hline 79 & 2 & amusement parks & 1 \\
\hline 80 & 2 & general med'l/surgical hospitals & 1 \\
\hline Total & 192 & & $100 \%$ \\
\hline
\end{tabular}

Table 2 presents the descriptive statistics in the study. Total sample 192 firms include 96 restaters and 96 non-restaters. It presents descriptive statistics for each variable. For example, the average number of female directors for the sample is 1.23 and the maximum number of female directors for our sample is 6 . 
Table 2

Descriptive Statistics In the Study

This table summarizes the variables used in the study

\begin{tabular}{|c|c|c|c|c|c|}
\hline Variable & Sample Size & Minimum & Maximum & Mean & Std. Dev. \\
\hline$D \_F d$ & 192 & 0 & 3 & 20 & .19 \\
\hline$D \_O s d$ & 192 & 1 & 8 & 7.79 & 3.025 \\
\hline Dir_15 & 192 & 0 & 0 & 1.42 & 1.649 \\
\hline$D \_4$ & 192 & 0 & 21 & 1.06 & 1.441 \\
\hline$D \_T 1$ & 192 & 3 & 6 & 1.23 & 3.088 \\
\hline D_Wn & 192 & 0 & 0 & 361 & 1.089 \\
\hline D_0 & 192 & 314 & 364000 & 37327.5 & 58318.87 \\
\hline Employees & 192 & 117751998 & 324275468750 & 18157272048. & 38745120558 \\
\hline Mktcap & 192 & &
\end{tabular}

D_Fd: Number of directors of failed companies on the board D_Osd: Number of total outside directors

Dir_15: Director over 15 years of tenure

Dir_4: Directors serving on over 4 boards

D_Tl: Total Number of Directors

D_Wn: Directors are women

D_0: Directors have 0 equity shares

Employees: Number of employees

Mktcap: Market capitalization.

Table 3 presents the correlation coefficient matrix. Results from the Table indicate that multi-collinearity among the independent variables is not a problem.

Table 3

Correlation Coefficients Matrix among Director Profile Variables

\begin{tabular}{|c|c|c|c|c|c|c|c|}
\hline & $D \_F d$ & D_Osd & D_15 & $D \_4$ & D_wn & D_O & Empl \\
\hline$D \_F d$ & 1 & & & & & & \\
\hline$D \_O s d$ & $.188 * *$ & 1 & & & & & \\
\hline$D \_15$ & .006 & .023 & 1 & & & & \\
\hline D_4 & .097 & $.474 * *$ & -.021 & 1 & & & \\
\hline$D \_W n$ & .039 & $.540 * *$ & .023 & $.29 * *$ & 1 & & \\
\hline$D \_0$ & $.247 * *$ & .061 & $-.19 * *$ & .013 & .029 & 1 & \\
\hline Empl & .120 & $.342 * *$ & .075 & $.43 * *$ & $.28 * *$ & -.099 & 1 \\
\hline
\end{tabular}

**, *: Significant at .05 and .1 levels respectively.

D_15: Director over 15 years of tenure

D_Osd: Number of outside directors

D_4: Directors serving on over 4 boards

D_Fd: Number of directors of failed companies on the board D_Wn: Directors are women

D_0: Directors that have 0 equity shares

Empl: Number of employees

Tables 4 and 5 present the results of mean value and mean difference of director profile between two groups: restaters and non-restaters. According to Table 5, three mean differences are significant. These are directors that serve over 4 boards (D_4), directors that are woman (D_Wn), and the size of the firm (employee). Independent samples $\mathrm{T}$ test indicates that restating firms, on average, have more directors that serve over 4 boards, more female directors, and greater size than matched non-restating firms. 
Table 4

Mean Value of Director Profile Variables

This Table summarizes the mean values of each variable for both groups: Restaters (1) and Non-Restaters (0)

\begin{tabular}{|c|c|c|c|c|c|}
\hline Director Profile & $\begin{array}{c}\text { Restater vs. } \\
\text { Non-restater }\end{array}$ & Sample Size & Mean & Std Dev. & Std. Error of Mean \\
\hline$D \_15$ & 1 & 96 & 1.27 & 1.512 & .167 \\
\hline & 0 & 96 & 1.56 & 1.770 & .181 \\
\hline$D \_4$ & 1 & 96 & 1.27 & 1.432 & .147 \\
\hline & 0 & 96 & .84 & 1.424 & .145 \\
\hline$D \_F d$ & 1 & 96 & .20 & .452 & .046 \\
\hline & 0 & 96 & .18 & .523 & .053 \\
\hline D_Wn & 1 & 96 & 1.41 & 1.07678 & .110 \\
\hline & 0 & 96 & 1.04 & 1.07524 & .109 \\
\hline D_Osd & 1 & 96 & 8.29 & 2.813 & .301 \\
\hline D_0 & 0 & 96 & 7.28 & 3.155 & .322 \\
\hline Empl & 1 & 96 & .77 & 1.364 & .140 \\
\hline & 0 & 96 & .84 & 1.991 & .203 \\
\hline PerOutDir & 1 & 96 & 51391 & 67576.754 & 6897 \\
\hline & 0 & 96 & 23263 & 43261.917 & 4415 \\
\hline
\end{tabular}

D_15: Director over 15 years of tenure

D_4: Directors serving on over 4 boards

D_Fd: Number of directors of failed companies on the board D_Wn: Directors are women

D_Osd: Number of outside directors

D_0: Directors have 0 equity shares

PerOutDir: Percentage of directors that are outsiders. Calculated as number of outside directors divided by total number of directors

Empl: Number of employees

Table 5

Independent Samples T Test for Equality of Means

This Table compares mean values of Director Profile between two groups:

Restaters and Non Restaters. Mean Difference is calculated as restater (1) - nonrestater (0). F Statistics, Significance level and T statistics are provided

\begin{tabular}{|c|c|c|c|c|}
\hline Director Profile & Mean Difference & F Statistics & Sig. & T Statistics \\
\hline$D \_4$ & .430 & 1.070 & $.039^{* *}$ & 2.080 \\
\hline$D \_F d$ & .023 & .12 & .729 & .324 \\
\hline$D \_w n$ & .3688 & .462 & $.019^{* *}$ & 2.369 \\
\hline Dir_15 & -.289 & 1.977 & .227 & -1.212 \\
\hline$D \_T l$ & .591 & .570 & .187 & 1.324 \\
\hline Dir_0 & -.075 & .231 & .761 & -.305 \\
\hline Empl & 28,128 & 9.248 & $.01^{* * *}$ & 3.435 \\
\hline PerOutDir & .05732 & 8.988 & .008 & 2.670 \\
\hline
\end{tabular}

**, ***: Significant at .05 and .01 levels respectively.

D_15: Director over 15 years of tenure

D_4: Directors serving on over 4 boards

D_Fd: Number of directors of failed companies on the board D_Tl: Total Number of Directors

D_Wn: Directors are women

D_0: Directors that have 0 equity shares

PerOutDir: Percentage of directors that are outsiders. Calculated as number of outside directors divided by total number of directors

Empl: Number of employees 


\section{Presentation and Discussion of Results}

This section presents the results of logistic regression analysis and discussion of hypotheses. According to Table 6 (see below), two variables are significant in the models: percentage of outside directors (PerOutDir) and the size of the firm (employee). Results indicate that firms with a lower percentage of outside directors are more likely to restate earnings and that firms with a greater size are more likely to restate earnings. The following section discusses the hypotheses.

\section{Table 6}

Results of Logistic Regression Models Based on Different Variables.

This table presents the results of logistic regression analyses.

Dependent Variable is whether the firm restated earnings or not. Restated earnings is coded as 1 and 0 otherwise. Independent Variables include director profile.

$P($ Restate Earnings $=1)=1 /\left\{1+\mathrm{e}^{-\mathrm{y}}\right\}$ Where $y=\alpha_{0}+\boldsymbol{B}_{1} *$ VAR1 $+\boldsymbol{B}_{2} *$ VAR2 $+\boldsymbol{B}_{3} *$ VAR3 $+\ldots \beta 9 *$ VAR9 VAR 1-VAR 9 are director characteristics

\begin{tabular}{|c|c|c|c|c|c|c|}
\hline & Model 1 & Model 2 & Model 3 & Model 3 & Model 4 & Model 5 \\
\hline D_0 & -.002 & & -.002 & & & \\
\hline$D \_15$ & -.190 & -.176 & & -.195 & & \\
\hline Dir_4 & $-.022^{\mathrm{a}}$ & -.011 & -.047 & -.130 & -.258 &. .007 \\
\hline$D \_F d$ & .045 & .042 & .063 & .030 & .948 & .096 \\
\hline D_Wn & .187 & .173 & & .230 & & $-2.234^{* *}$ \\
\hline PerOutDir & $-2.319^{* *}$ & & & & $-2.204^{* *}$ \\
\hline Empl & $.0001^{* * *}$ & $.0001^{* * *}$ & $.0001^{* * *}$ & & & $.0001^{* *}$ \\
\hline Log Likelihood & 245.69 & 245.43 & 251.22 & 168.42 & 255.03 & 247.899 \\
\hline Model $x^{2}$ & $19.29 * * *$ & $18.87^{* * *}$ & $13.255^{* *}$ & $12.32^{* *}$ & $9.754^{* *}$ & $11.375^{* *}$ \\
\hline
\end{tabular}

a B coefficient

***,**, Significant at .01 and 05 levels respectively.

D_4: Directors serving on over 4 boards

D_Fd: Number of directors of failed companies on the board D_15: Director over 15 years of tenure

D_Wn: Directors are women

D_0: Directors have 0 equity shares

PerOutDir: Percentage of directors that are outsiders. Calculated as number of outside directors divided by total number of directors

Empl: Number of employees

Hypothesis 1: The Greater the Equity Ownership of a Director, the Greater the Probability that the Firm on Whose Board He or She Serves Has Restated Suspect Earnings.

This hypothesis was not supported. The correlation was negative as predicted, but the correlation was not significant. Since many directors receive fees along with shares, any share effect may not be that great. The market value of individual director's equity holdings was not known. Since we used a binary approach-share owner vs. no share ownership - the regression model did not discriminate between large and small shareholders. A director may own ten shares, but this level and value of ownership may be too small to introduce any bias.

In addition, general stock market conditions may affect a director's behavior. If the stock market as a whole is not performing well, even directors with substantial equity holdings who might otherwise be tempted to go along with earnings manipulations may refrain from doing so because the market is not presently rewarding higher earnings. Or, as we suggested with respect to the first hypothesis, whether directors are effective may depend on individual character, not on the level of pay.

Hypothesis 2: The Longer a Director Has Served on a Board, the Greater the Probability that the Firm on Which He or She Serves Has Restated Suspect Earnings. 
This hypothesis was not supported. The correlation was insignificant and negative. It is equally probable (or improbable) that long-serving directors will be associated with non-restating firms as with restating firms. Discerning fraud may require knowing the firm very well; in some cases, longer-tenured directors may have the firm-specific knowledge needed to spot suspect financial numbers. Another possibility is that new directors may not be any more probing than longer-serving board members. Some governance experts have argued that boards socialize new members, encouraging these appointees "to go along to get along" and to be quiet until they have learned the ropes. Such socialization may render even newer board members ineffective. In any case, our finding with regard to earnings restatements is consistent with Pan and Shin's conclusion (2004) that earnings management does not decrease as the tenure of board members declines.

Hypothesis 3: The Greater the Number of Board Appointments Held by a Director, the Greater the Probability that the Firm on Which He or She Serves Has Restated Suspect Earnings.

This hypothesis was not supported. The correlation was insignificant and negative, not positive as predicted. The character of the individual director may be more decisive than the number of boards on which he or she serves or it could be that directors serving on many boards gain wide experience that makes them more shrewd and adept when it comes to discerning fraud. The latter possibility would help explain why the correlation is positive, not negative.

In general, understanding the effect of multiple directorships and interlocks on corporate performance and restatements is difficult because it is hard to know which way the causality runs. Interlock may render a board less effective, thus contributing to poor performance, earnings manipulation, and a greater likelihood of restatement of earnings. On the other hand, a struggling firm may recruit one or more CEOs of well-performing companies. If these CEOs are in high demand, interlock may be the result of restatements that occurred prior to our 2002-2004 window. Booth and Deli (1996) and Fich and White (2001) have raised this possibility that performance is a predictor of interlock, not the reverse. Our data is not sufficiently fine-grained to allow us to rule out this latter possibility. Nor can we rule out the possibility that the causality runs in one direction at some firms but in the opposite direction at other companies, producing effects that cancel each other out.

Hypothesis 4: A Director Who Is the CEO of a Failed Company Has a Greater Probability of Being on a Board of a Company that Has Restated Suspect Earnings.

This hypothesis was not supported. The correlation was positive as predicted but insignificant. The maximum number of failed directors on a single board in our sample was three. Since the percentage of a board's directors that come from failed companies may be more significant than the absolute number of such directors, we standardized the number of directors as a percentage of board directors and ran the regression once more. Again, the correlation turned out to be insignificant.

The failure to find a significant positive correlation between earnings restatements and failed directors could be due to several factors. First, not every firm failure is attributable to fraud. Some failed company directors may have served on boards of companies in very competitive or dying industries. These companies may have gone bankrupt through no fault of their directors. Second, failed directors may actually help a firm avoid restatements. Some evidence suggests that failed directors are as diligent as anyone else on the board. Sonnenfeld (2002) notes that board attendance by failed company directors has been as good as that of other directors. At a minimum, this result suggests that researchers should be wary of stigmatizing failure. Failed directors may turn out to be good board members if they have learned from past mistakes or are especially keen to do better. R3, the British association for business recovery executives, has adopted this more charitable perspective, arguing that failed directors should be retrained rather than barred from service (Zea, 2002).

Hypothesis 5: A Female Director Has a Lesser Probability of Being on a Board of a Company that Has Restated Suspect Earnings.

This hypothesis was not supported. The failure to find a correlation could be due to several factors. First, the number of women on boards is simply not that great. The mean number is 1. It might be more revealing to look 
for a correlation between the percentage of female board members and earnings restatements. Therefore, we also divided the number of female directors by total directors on the board and re-ran the regression. The results were the same: no significant correlation. Our result, broadly interpreted, is consistent with the work done by Erhardt et al (2003). They failed to find any significant positive correlation between the percentage of female board directors and return on assets or return on equity at 200 large cap US firms. Having women on the board does not seem to lead to good returns and so would not reduce the incentive for the firm to manipulate earnings.

Hypothesis 6: A Board with a Smaller Percentage of Outside Directors Has a Greater Probability of Being Associated with a Firm that Has Restated Suspect Earnings.

This hypothesis was confirmed. Since the number of outside directors varied so widely, we standardized this variable by dividing the number of outside directors on a given board by the total number of directors on the board. Since independent directors are less subject to CEO control than inside directors, they may be more willing to ask tough questions. In this era of increased director liability, genuinely independent directors may be more inclined to press auditors to investigate thoroughly and to test financial results carefully. If several directors are willing to speak up, others may feel empowered to do so as well, resulting in better scrutiny of managerial behavior and of financial statements.

Hypothesis 7: A Director of a Larger Firm Has a Greater Probability of Being on the Board of a Firm that Has Restated Suspect Earnings.

This hypothesis was confirmed. Firm size and the restatement of earnings were strongly positively correlated. The size of the firm often is a highly significant variable in finance studies. Large firms are so distinctive as to constitute a population unto themselves. As we noted in our discussion of the hypothesis, larger firms have more opportunities to manipulate earnings. These opportunities are built into the structure of the large firm. Good judgment and courage, by contrast, are not built into a director profile. However, we would caution that this result could be an artifact of our methodology. Since restatements by large firms are typically more widely reported in the financial press, our database may have a built-in bias toward these firms. The Google search engine is more likely to find a news item that appears in fifteen or twenty newspapers or magazines than a single item buried in a regional newspaper.

\section{CONCLUDING THOUGHTS}

Our results point in two opposing directions. Our model suggests that having independent directors on the board may lessen the probability of an earnings restatement, especially when outside directors constitute a significant percentage of the board. When independent directors achieve a critical mass, it looks as if these board members help insure that management reports accurate earnings. Although this finding accords with the previously cited studies suggesting that board independence reduces fraud and leads to better returns, it needs to be confirmed by additional longitudinal studies. When Bhagat and Black (2002) did a large-scale, long-term study of board independence and firm performance of large cap American companies, they found no significant correlation between director independence and firm profitability. Even when firms responded to poor performance by adding more outside directors, profitability did not improve. A similar longitudinal study should be done correlating director independence and other traits with restatements of suspect earnings.

While the positive correlation between board independence and the lower probability of earnings restatements is interesting, what we find even more striking is the apparent irrelevance of all other aspects of the director profile (e.g., board tenure, gender, level of compensation, etc.). This lack of significance suggests that much current governance research is on the wrong track. This research has tended to focus on board composition (e.g., how many long-serving directors are on the board?) and structural features (e.g., does the board have an audit committee composed of CPAs?). Yet, when Larker et al (2004) modeled 14 governance factors, they, like we, found little positive correlation between these factors and firm results: "the typical structural indicators of corporate governance used in academic research and institutional rating services have very limited ability to explain managerial behavior and organizational performance" Larker et al, 2004, p. 1). Our failure to find any significant correlation between specific director traits and the probability of earnings restatements is consistent with recent 
studies showing that companies receiving a good corporate governance rating based, in part, on director profile and board structure have neither higher quality earnings (Koehn and Ueng, 2005) nor better stock returns (Larker et al, 20045) than companies getting lower governance ratings.

The current formal structural approach to governance ignores the tone at the top and firm-specific dynamics. As Turley and Zaman $(2005$, p. 1) put it, "extant [governance] literature fails to give due consideration to the organizational and institutional context" in which directors and committees operate. How a firm performs may well depend upon whether management acts in ways that empower or emasculate the board. It would be useful to know details such as: Does management provide directors with complete financial information? How much in advance of the meeting do directors receive this data? Is the data given to them in a format that enables them to make accurate quarter to quarter comparisons of debt levels, cost of capital, etc.? Or does management keep changing the mode of presentation?

How management conducts board meetings may matter as well. Does management signal that questions are welcome? Does management eat up the entire board meeting with PowerPoint presentations, or are board members given ample time to ask questions? Exploring board room dynamics is going to prove difficult. Since researchers usually do not have access to transcripts or even minutes of board meetings, it is impossible to know what was said, inferred, or glossed over. Even if board minutes were widely available, investigators would still have difficulty judging the tone of the meeting and deliberations. Were the directors serious in their questioning, or was the meeting treated like a joke? Qualitative institutional and cultural factors almost certainly matter, yet to date governance has been approached with quantitative mindset. How many women do we have on the board? How many CPAs are on the audit committee? One can understand why the market has generally been skeptical about governance reforms: restating companies that subsequently alter their governance practices and director profile do not experience much of a market gain (Farber, 2004).

We welcome new research that seeks to explore the effect of managerial power on board dynamics. Adams and Ferreira (2004), for example, have argued that CEOs face a tradeoff when it comes to sharing useful information with board members. On the one hand, CEOs who reveal more information likely get more and better advice from board members. On the other hand, a better informed board may monitor the CEO more closely. Those CEOs who do not want to see their power curtailed may resist sharing much information. In addition, how deeply board members probe appears to be a function of management's power to remove board members (Warther, 1998) and to structure the board in the first place (Hermalin and Weisbach, 1998). Firms with more powerful CEOs-i.e., CEOs who founded the company, who are the sole insider on the board, and/or who have several job titles - have more variable stock returns (Adams et al, 2004). Such variability may indicate an absence of earnings manipulation and, hence, a lower probability of the need to restate suspect earnings. Or it may indicate that the earnings are rising and then falling dramatically as the company later is forced to restate earnings. Although the Adams study is not clear on the possible link between possible earnings manipulation and earnings variability, it does point to the need for researchers to control for CEO power (which may itself be an endogenous function of how often a firm has been forced in the past to restate earnings) when modeling the efficacy of board governance. If the real governance issue is the magnitude of the CEO's power and the extent to he or she controls the institutional context, then adding a few women to the board or removing directors who were CEOs of failed companies likely will have little effect on the earnings quality of a firm.

\section{AUTHOR INFORMATION}

Chingliang Chang completed his master's degree in business administration at the Manchester Business School, United Kingdom. He lectures on corporate finance, foreign exchange markets, and international financial markets as an instructor in the Department of International Business, Kainan University, Taiwan. His research interests include corporate governance, initial public offerings (IPO), seasoned equity offerings (SEO), and share repurchases.

Joe Ueng is the Cullen Professor of Finance and the Chair of Department of Economics, Finance, and Decision Information Sciences at the University of St. Thomas in Houston. Current research interests include corporate governance, international investment, and mergers and acquisitions. He has published in International Review of 
Financial Analysis, Managerial Finance, Journal of Applied Business Research, Multinational Business Review, The Journal of Accounting and Finance Research, Review of Business, The Journal of Business Economics Research, Midwest Review of Finance and Insurance, and International Journal of Business Research. He is a chartered financial analyst (CFA).

Daryl Koehn holds the Cullen Chair of Business Ethics at the University of St. Thomas in Houston, Texas. She has a Ph.D. in ethics (University of Chicago), an MBA in finance (Northwestern University), and a BA in both philosophy (University of Chicago/magna cum laude) and philosophy, politics and economics (Oxford University). She has written many articles on ethics and corporate governance and six books on the subject-Trust in Business; The Ground of Professional Ethics; Corporate Governance/Ethics Across the Board; Rethinking Feminist Ethics; Local Insights, Global Ethics for Business; and The Nature of Evil. Her fellow business ethicists elected her President of the Society of Business Ethics, and she served on the SBE board from 2000-2005.

\section{REFERENCES}

1. Adams, R., H. Almeida, and D. Ferreira. 2004. "Powerful CEOs and their impact on corporate performance." Forthcoming in Review of Financial Studies.

2. Adams, R. and D. Ferreira. 2004. "Gender diversity in the boardroom." ECGI Finance Working Paper No.57/2004. http://ssrn.com/abstract=594506.

3. $\quad$ Adler, R. 2001. "Women and profits." Harvard Business Review 79 (10): 30

4. Agrawal, A. and S. Chadha. 2005. "Corporate governance and accounting scandals." Journal of Law and Economics, October Akhigbe, A., R. Kudla, and J. Madura. 2005. "Why are some corporate earnings restatements more damaging?" Applied Financial Economics 15 (5): 327-336.

5. Akhigbe, A., R. Kudla and J. Madura. 2005. "Why are some corporate earnings restatements more damaging?" Applied Financial Economics 15: 327-336.

6. Balsam, S., E. Bartov. And C. Marquardt. 2002. "Accruals management, investor sophistication, and equity valuation: Evidence form 10-Q filings." Journal of Accounting Research (40): 987-1012.

7. $\quad$ Barr, Stephen. 1998. "Misreporting Results." CFO Magazine (December).

8. Beasley, M. 1996. "An empirical analysis of the relation between board of director composition and financial fraud." The Accounting Review 71 (October): 443-465.

9. Bergstresser, D. and T. Philippon. 2004. "CEO incentives and earnings management." Working paper.

10. Bhagat, S. and B. Black. 2002. "The non-correlation between board independence and long-term firm performance." The Journal of Corporation Law (University of Iowa) 27: 231-272.

11. Bhojraj, S. and P. Sengupta. 2003. "Effect of corporate governance on bond ratings and yields: The role of institutional investors and outside directors." Journal of Business 76: 455-475.

12. Bonn, I., T. Yoshikawa, and P.H. Phan. 2004. "Effects of board structure on firm performance: A comparison between Japan and Australia." Asian Business and Management 3 (1): 105-121

13. Booth, J.R. and D.N. Deli. 1996. "Factors affecting the number of outside directorships held by CEOs." Journal of Financial Economics 40(1): 81-104.

14. Bradshaw, M.T., S.A. Richardson and R.G. Sloan. 2001. "Do Analyst and Auditors Use Information in Accruals?” Journal of Accounting Research (39): 45-75.

15. Brennan, K. 2005. "The rising incidence of D \& O claims and prosecutions of directors in Asia." Presentation given to Asian Corporate Governance Association, week of September 8, Hong Kong.

16. British Broadcasting Company. 1998. "Call for action on rogue directors." January 12.

17. Brown, L.D. and H.N Higgins. 2001. "Managing earnings surprises in the US versus 12 other countries." Journal of Accounting and Public Policy 20 (Winter): 373-398.

18. Burns, N. and S. Kedia. 2003. "Do executive stock options generate incentives for earnings management? Evidence from accounting restatements." Working Paper.

19. Callen, J., J. Livnat, and D. Segal. 2003a. "Accounting restatements: Are they always bad news for investors?" Working paper, University of Toronto and New York University.

20. Callen, J., W. Robb, and D. Segal. 2003b. "Revenue manipulation and restatements by loss firms." Working paper, University of Toronto.

21. Catalyst. 2004. "The bottom line: Connecting corporate performance and gender diversity." www.catalystwomen.org. 
22. Collins, D., A. Reitenga, and J.M. Sanchez. "The managerial consequences of earnings restatements." Working paper, University of Memphis.

23. Core, J., R.W. Holthausen, and D. Larcker. 1999. "Corporate governance, CEO compensation, and firm performance.” Journal of Financial Economics 51: 371-406.

24. Cox, T., Jr. Cultural diversity in organizations: Theory, research and practice. San Francisco: Koehler Publishing.

25. Dechow, P.M., R.G. Sloan, and A. Sweeney. 1996. "Causes and consequences of earnings manipulation: An analysis of firms subject to enforcement actions by the SEC." Contemporary Accounting Research 13 (1): 235-50.

26. Dechow, P.M., and D. J. Skinner. 2000. "Earnings management: Reconciling the views of accounting academics, practitioners, and regulators." Accounting Horizons 14 (2): 235-50.

27. Dechow, P.M., L. A. Myers and C. Shakespeare. 2004. "Playing with assumptions to report a rosy future today: the role of corporate governance in the reporting of asset securitization." Working paper at www.aaanz.org/web2004/papers/dechowp-GOV.pdf.

28. DeFond. M. and J. Jiambalvo. 1991. "Incidence and circumstances of accounting errors." The Accounting Review (July): 643-655.

29. Eilefsen, A. and W.F. Messier, Jr. 2000. "The incidence and detection of misstatements: A review and integration of archival research." Journal of Accounting Literature 19: 1-43.

30. Erickson, M., M. Hanlon, and E. Maydew. 2003. "Is there a link between executive compensation and accounting fraud?" Working paper.

31. Erhardt, N.L., J.D. Werbel, and C.B. Schrader. 2003. "Board of director diversiy and firm financial performance." Corporate Governance: An International Review 11 (2): 102-111.

32. Farber, D. 2004. "Restoring trust after fraud: Does corporate governance matter?" Working paper, Michigan State University.

33. Ferris, S., M. Jagannathan, and A.C. Pritchard. 2003. "Too busy to mind the business? Monitoring by directors with multiple board appointments." Journal of Finance 58(3): 1087-1112.

34. Fich, E. and L. White. 2001. "Why do CEOs reciprocally sit on each other's boards?" New York University Center for Law and Business Working Paper \#CLB-01-002.

35. Fich, E. and L. White. 2003. "CEO compensation and turnover: The effects of mutually interlocked boards." Wake Forest Law Review 38(3): 935-959.

36. Fich, E. and A. Shivdasani. 2005. "Are busy boards effective monitors?” Paper presented at American Finance Association.

37. Fich, E.M and A. Shivdasani. 2005. "Financial fraud, director reputation, and shareholder wealth." Working paper.

38. Filatotchev, I. and S. Toms. 2003. "Corporate governance, strategy and survival in a declining industry: A study of UK cotton textile companies.” Journal of Management Studies 40: 895- 920.

39. General Accounting Office. 2002. "Financial Statement Restatements: Trends, Market Impacts, Regulatory Responses, and Remaining Challenges." At www.gao.gov/new.items/d03138.pdf.

40. Hallock, K. 1997. "Reciprocally interlocking boards of directors and executive compensation." Journal of Financial and Quantitative Analysis 32 (September): 331-344.

41. Harris, J. and P. Bromiley. 2005. "Incentives to cheat: The influence of executive compensation and firm performance on financial misrepresentation." Organization Science 18(3): 350-367.

42. Hermalin, B. and M. Weisbach. 1998. "Endogenously chosen boards of directors and their monitoring of the CEO." American Economic Review 88: 96-118.

43. Jehn, K., G. B. Northcraft, and M. A. Neale. 2000. "Why Differences Make a Difference: A Field Study of Diversity, Conflict, and Performance in Workgroups." Administrative Science Quarterly 44: 741-763.

44. Kinney, W.R.,Jr. and L.S. McDaniel. 1989. "Characteristics of Firms Correcting Previously Reported Quarterly Earnings." Journal of Accounting and Economics 11: 71-94.

45. Koehn, D. and J. Ueng. 2005. "Evaluating the evaluators: Should investors trust corporate governance metrics ratings?" Journal of Management and Governance 9(2): 111-128.

46. Larker, D.F., S.A. Richardson and A. Iremtuna. 2004. "How important is corporate governance?" September. Working paper available at SSRN website.

47. Livnat, J. and C.E.L. Tan 2004. "Restatements of quarterly earnings: Evidence on earnings quality and market reactions to the originally reported earnings." Working paper, New York University. 
48. Milliken, F.J. and L. L. Martins. 1996. "Searching for common threads: Understanding the multiple effects of diversity in organizational groups." Academy of Management Review 21: 402-433.

49. Morningstar-Dow Jones \& Company. 2005. "Footnotes: Recent US earnings restatements." September, 9, http://news.morningstar.com.

50. Myers, J., L. Myers, Z. Palmrose, and S. Scholz. 2004. "Mandatory auditor rotation: Evidence from restatements." Working paper.

51. Owers, J.E. and C.M. Lin. 2002. "The Informational Content and Valuation Ramifications of Earning Restatements." International Business and Economics Research Journal 1(5): 71-84.

52. Palmrose, Z-V., V. J. Richardson, and S. Scholz. 2001. "Determinants of market reactions to restatement announcements." Working paper, University of Southern California and University of Kansas.

53. Palmrose, Z., V. Richardson, and S. Scholz. 2004. "Determinants of market reactions to restatement announcements." Journal of Accounting and Economics 37 (1): 1-32.

54. Park, Y.W. and H.H. Shin. 2004. "Board composition and earnings management in Canada." Journal of Corporate Finance 10: 431-457.

55. Pelled, L. H., K. M. Eisenhardt, and K. R. Xin. 1999. "Exploring the black box: An analysis of work group diversity, conflict and performance." Administrative Science Quarterly 44: 1-28.

56. Provenzo, A. 2002. "Allen Greenspan: Ayn Rand's failed student.” Capitalism Magazine. August 26. At http://www.capmag.com/article.asp?id=1821.

57. Public Policy Forum. 2003. "Diveristy and tomorrow's profits: Women in corporate leadership." Milwaukee Women, Inc. At www.iwpr.org/PDF/05_Proceedings/Dickman_Anneliese.pdf

58. Ranzijn, M. and S. Verboom. 2004. "Connecting corporate performance and gender diversity." MA thesis.

59. Richard, O. C., T. Barnett, S. Dwyer, and K. Chadwick. (2004). "Cultural diversity in management, firm performance, and moder role of entrepreneurial orientation dimensions." Academy of Management Journal 47 (2): 255-266.

60. Richardson, S. A., A. I. Tuna, and M. Wu. 2002. "Predicting earnings management: The case of earnings restatements." Working paper, University of Pennsylvania.

61. Rosener, J. 2005. "Women on Corporate Boards Make Good Business Sense." At WomensMedia.com.

62. Salavei, K. and N. Moore. 2005. "Signals Sent by Financial Statement Restatements." Working paper, University of Connecticut.

63. Security Management Today. 2001. "Directors in the Experian dock." September.

64. Sonnenfeld, J.A. 2002. "What makes great boards great?" Harvard Business Review, September.

65. Thomas, C. 2005. "The impact of diversity and independence on board effectiveness." Speech given to European Professional Women's Network, Paris, February 10.

66. Thomsen, Steen. 2004. "Blockholder ownership, dividends, and firm value in continental Europe." Paper presented at ISNIE conference.

67. Tsui, A., T. Egan, and C. O'Reilly. 1991 "Being different: Relational demography and organizational attachment." Administrative Science Quarterly 37: 549-579.

68. Turley, S. and M. Zaman. 2004. "Global presence yet no difference: Corporate governance effects of audit committees." Journal of Management and Governance 8 (3): 305-332.

69. Turner, J.L. and J. T. Sennetti. 2001. "Post-audit restatement risk and audit firm size." Journal of Forensic Accounting 2: 67-94.

70. Van Der Zahn, J.L.W. 2004 "Association between gender and ethnic diversity on the boards of directors of publicly listed companies in South African and intellectual capital performance.” Working paper, Singapore Management University.

71. Warther, V.A. 1998. "Board effectiveness and board dissent: A model of the board's relationship to management and shareholders." Journal of Corporate Finance 4: 53-70.

72. Wharton Communications. 2002. "Why firms restate annual earnings and why investors should beware." October 23, www.upenn.edu/reseearchatpenn/article.php86\&bus.

73. Wilson, W. 2005. "The Information Content of Earnings Following Restatements." Working paper, University of North Carolina at Chapel Hill.

74. Wu, M. 2002. "Earnings Restatement: A Capital Market Perspective." Working paper, New York University.

75. Zea, A. (2002). "Failed directors should be retrained." Accountancy Age, July 4. 
NOTES 